Research Article

\title{
Opportunities and Obstacles for Information Technology Start-Ups in Europe: A Comparison between Germany and Latvia
}

\author{
Pierre G. Keller \\ Banku Augstskola School of Business and Finance, K.Valdemāra, Riga, Latvia \\ pierrekeller91@outlook.com
}

Received date: 16 February 2017; Accepted date: 23 May 2017; Published date: 1 September 2017

Academic Editor: Veit Köppen

Copyright (C) 2017. Pierre G. Keller. Distributed under Creative Commons CC-BY 4.0

\begin{abstract}
Smartphones, e-mobility, Internet of Things (IoT) - our world is situated in the middle of digitalization, product life cycles are short and innovations are particularly welcome in the information technology (IT) industry, as they imply a great opportunity for lucrative businesses. In particular, innovative start-up companies are playing an increasingly important role in this context. However, a strict consideration of country-specific circumstances (Germany and Latvia have been selected as examples) has to be made to evaluate founding culture. The following paper focusses on these issues in different ways and gives an insight of the entrepreneurial situation in the respective countries to the reader in the way how different circumstances affect start-ups and how the future development in the countries should be. The results show that - besides Germany - Latvia also portrays a very attractive market with even hidden potential for IT start-ups.
\end{abstract}

Keywords: Business Formation, Entrepreneurship, Information Technology, Start-up

\section{Introduction}

IoT implies great influence on industrial firms; machines and products are increasingly connected to the Internet (The Economist, 2015). Local cultures are further made more visible; this means, located localities are connected with necessary connections to companies (Chirjevskis \&
Ludviga, 2009; Lange, Leleux \& Surlemont, 2003).

Innovations, in particular, play a special role in digitalization, as they simply help to promote it (i.e. through knowledge spillovers) (De Clercq, Hessels \& Van Stel, 2008). In this context, research articles have already pointed out the special role of

Cite this Article as: Pierre G. Keller (2017)," Opportunities and Obstacles for Information Technology Start-Ups in Europe: A Comparison between Germany and Latvia" Journal of EU Research in Business, Vol. 2017 (2017), Article ID 422546, DOI: 10.5171/2017.422546 
start-up companies, which have a high potential for innovations, imply positive effects on economic growth as well as job creation, foster globally competitive economies and support the modernisation of economies (Aleksejeva \& Aleksejeva, 2015; Ammetller, Rodríguez-Ardura \& Lladós-Masllorens, 2014; Bednarzik, 2000; Hessels \& Van Stel, 2011; Lerner, 2010; Rajaei, Yaghoubi \& Donyaei, 2011; Welter, 2010). Thus, it is useful for each country to have a certain basic business foundation culture. In the United States of America, it was shown that the result of an adoption of new technologies led to a boost in productivity during the second half of the 1990s (Dobele, 2011). In this context, three research questions can be evaluated as important:

- RQ1: How is the start-up behaviour, especially in the IT industry, dependent on national circumstances?

- RQ2: Which national circumstances affect start-ups in Germany and Latvia and which pillars of their respective business ecosystem competitiveness are beneficial or unbeneficial for startups?

- RQ3: How beneficial are the Business Innovation Ecosystems in Germany and Latvia for start-ups in both countries, which measures do both Germany and Latvia take to establish or strengthen their business foundation culture - especially in IT industry - and which venture possibilities exist in these countries?

In order to answer these questions, a comparative analysis between Germany and Latvia takes place. This selection implies a comparison of Central and Eastern Europe, there is, thus, a spatial distance, which generates cultural differences. Likewise, Germany is a country characterized by high product quality and offering various measures for support to start-ups (Ammetller et al., 2014; Gebhardt, 2012), while Latvia has less of such measures or is only at the beginning to use them more often (Manolova, Eunni \& Gyoshev, 2008). While Germany can undoubtedly be described as an ITaffine country, Latvia, which is known by its large forestry, is for the moment not capable of such a big affinity (Audretsch \& Keilbach, 2007; Schwab, 2016). The answer of the above mentioned research questions should indicate at weaknesses, which then could be eliminated or improved, or at unseen potential, that could be aroused. Therefore, the aim of this research is subject to a better understanding of the dependent variables according to the company formation circumstances as well as to the exploration of country-specific strengths and weaknesses with regard to start-up culture and start-up circumstances, especially in IT industry.

\section{Indicators of entrepreneurial activity and success}

According to Carraher, Buchanan and Puia (2010), healthy economies are dependent on the growth created from business formations. For instance, entrepreneurship promotes regional development in noncore regions, as they generate higher productivity at the firm level as well as a contribution to added social values (Baumgartner, Pütz \& Seidl, 2013). Nevertheless, business foundations need advanced knowledge and capabilities, which are often missing in a start-up company, especially in the IT industry (Ammetller et al., 2014). In this case, external business support services can be used to fill this gap, i.e. if the founders do not have experience as entrepreneurs.

The quality of infrastructure is another important factor which influences entrepreneurship. It combines communication, quality of roads, infrastructure of public transport, financial as well as educational and public utilities infrastructure (Aleksejeva \& Aleksejeva, 2015). All these mentioned quality determinants of infrastructure obviously imply effects on companies - and, thus, start-ups.

Furthermore, like Landes (2000) argued, cultural differences explain a high amount of cross-country differentials in growth and performance, i.e. through varying power distance, individualism and masculinity, which all affect economic performance (Edwards, 2002). This fact can be explained by factors of the so-called Need 
for Achievement (i.e. effect of consciousness), which is a main driving force of entrepreneurial behaviour and is affected significantly by goal orientation, conscientiousness (higher conscientiousness leads to higher levels of Need for Achievement), cognitive complexity (high cognitive complexity leads to lower Need for Achievement) and gender (being male leads to higher levels of Need for Achievement) (Carraher et al., 2010). The last mentioned point somehow explains the fact of less female founders in comparison to males (Elam \& Terjesen, 2010). Therefore, cultural differences indicate the amount of entrepreneurial activity in different countries. In this context, a possible mediator effect of Need for Achievement could be explored in further studies.

Finally, political and legal environment, access to finances, recruitment of professional and well-motivated personnel further influence entrepreneurial activities and success, as it was shown in several studies before (i.e. Dobele, 2011; Romaní, Didonet, Contuliano \& Portilla, 2013). Thus, it appears obvious that an analysis of these circumstances is necessary to ensure the comparability of Germany and Latvia. Therefore, this analysis is subdivided into a general country analysis (see Chapter 3) and a country analysis, which specifically examines the possibilities of founding start-ups in the IT industry (see Chapter 4).

\section{Country analysis of Germany and Latvia}

In Germany, representing a Central European country, and Latvia, representing an Eastern European country, entrepreneurship portrays an opportunity for especially younger people; not only materially profitable, but intellectual rewarding and creativity and analytical skills rising (Bisoux, 2002).

Generally, entrepreneurship capital in IT industry, which measures the entrepreneurial importance in regions, is dependent on many regional factors (the measurement of Entrepreneurship capital is a common problem, which won't be described more in detail, but nevertheless, an accepted approach underlies in the relation of new firms venture capital in a region and the respective population); whereas unemployment rate and business tax level lead to significant lower entrepreneurship capital, the R\&D intensity, population density, industry diversity index as well as the locational attractiveness, in contrast, lead to significant higher results (Audretsch \& Keilbach, 2007). As it was also explained above, it is therefore worth to investigate national differences, which could influence the entrepreneurial activities (Peterka \& Saric, 2015).

\section{Germany as a forerunner of creating a business start-up culture in the $\mathrm{EU}$}

In the beginning, a brief summary is given to create a rough picture of the country's circumstances.

Germany, which has a population of about 81 million citizens, can be seen as a meaningful country within the EU (European Union, 2015a). It accounts $16 \%$ of the EU's total population and generates a Gross Domestic Product (GDP) of 3.026 trillion $€$ in 2015, which, in the sense of comparability, yields a GDP per capita of $37,275 €$ (which is a rise of $1.2 \%$ with regard to 2014) (European Union, 2015a; The World Bank, 2015a). Furthermore, GDP rose by $1.7 \%$ in 2015 (The World Bank, 2015b).

External business support services in Germany are supplied by several institutions; i.e. from the technology centres in Germany or the KfW Group (KfW) (Ammetller et al., 2014; KfW Research, 2016). Nevertheless, the founder ratio development is declining for the last 13 years (see Appendix 1) (KfW Research, 2016; Statista, 2017a). Within these foundations, $44.3 \%$ discovered a worldwide market novelty, which has to be considered as a highly positive fact (Statista, 2017b). Apart from that, $21 \%$ of ventures are located in the IT industry (KfW Research, 2016).

Besides institutional support, also political measures are present for entrepreneurial support, namely the High-Tech Start-up Fund from the Federal Ministry for Economic Affairs and Energy or the Entrepreneurial Regions Programme (ERP), which initially was created as a policy response to the economic crisis after the breakdown of 
the East German economy in 1989 (Federal Ministry for Economic Affairs and Energy, 2016a; Gebhardt, 2012). However, the effect of the concept of stable entrepreneurship within times of crisis, which was pursued by ERP, was that start-ups using ERP during financial crisis were significantly more characterized by their robustness, in particular with regard to the insolvency rate, than start-ups that didn't use ERP (Gebhardt, 2012).

At last, German Ministry of Education and Research (BMBF) uses the so-called Innovative Regional Growth Core (IRGC) programme, which is characterized by investments for promising start-ups without an adequate venture capital basis (Gebhardt, 2012). In 2015, the number of start-ups in Germany was for the first time since 2011 higher than those, which were liquidated (Federal Ministry for Economic Affairs and Energy, 2016b).

In summary, Germany can be seen as a pioneer within EU regarding support of founding ambitions, especially external business support.

\section{Start-up-potential of Latvia}

Germany and Latvia are connected through an important asset: Germany portrays one of the most relevant import partners for Latvia, which includes nearly 2 million citizens (about $0.4 \%$ of total EU) and whose land is covered $40 \%$ by woodlands (European Union, 2015b).

In comparison to the above mentioned macroeconomic data of Germany, Latvia's GDP, which was 24.378 billion $€$ in 2015, rose by $2.7 \%$ (European Union, 2015b; The World Bank, 2015c). Furthermore, even if the GDP per capita with $12,274 €$ is much lower than that in Germany, Latvia achieved a triple as high growth as Germany, namely 3.7\% (European Union, 2015b; The World Bank, 2015d). Within this growth, the most important sectors of Latvia were wholesale and retail trade, transport, accommodation and food services (25.2\%), industry (16.4\%) and public administration, defence, education, human health and social work activities (15.7 \%) (European Union, 2015b).
Social entrepreneurship, which is regarded as an important part of the economic future because of employment promotion, poverty risk reduction, social and economic solution and entrepreneurial skills enhancement, is weak in Latvia, as the social enterprises rate in Latvia only reaches $1.9 \%$, which is below the European average (Dobele, 2011).

Regarding Latvia's business environment, the main impact is exerted by public policy, which provides sustainable and predictable manifestations in tax and innovation policy, investment environment and lending policy (Geipele, Geipele, Staube, Ciemleja \& Zeltins, 2016a).

Apart from that, Latvia has a value system for the promotion of entrepreneurship in general, however due to its slowresponding regulatory framework, a high potential of raising entrepreneurial aspirations is imaginable, i.e. through an initiation of adequate programs (Manolova et al., 2008).

Regarding IT, in higher-income countries, technologies are in general more widely available than in lower-income countries, which lead to a disadvantage of Latvia in comparison to Germany (Hessels \& Van Stel, 2011).

However, in summary, it is important to note that a positive environment for startup companies is prevailing in Latvia. This hypothesis is supported by the growing number of start-up companies in Latvia (Centrālās statistikas pārvaldes datubāzes, 2016a).

\section{Comparison of Global Competitiveness between Germany and Latvia}

Global Competitiveness Index (GCI), as a kind of PESTEL analysis approach, examines and compares 138 different economies with their respective business ecosystems regarding competitiveness (expert survey with a 7-point Likert scale) and examines business ecosystems (Schwab, 2016). Therefore, it is a useful tool to evaluate the business environments of Germany and Latvia in a more detailed way. 
In Comparison, Germany reached the fifth place with a total score of 5.57, while Latvia reached the $49^{\text {th }}$ place and a score of 4.45 (Schwab, 2016).

The following table illustrates the result of dividing the total scores into the 12 main components (sub-indexes) of the GCI. The respective placement of the countries within country comparison is given in brackets in order to demonstrate strengths and weaknesses of Germany and Latvia in the relevant categories.

Table 1: GCI Sub-indexes for Germany and Latvia in 2016 from Schwab (2016)

\begin{tabular}{|l|l|l|}
\hline Sub-indexes (Pillars) & Germany & Latvia \\
\hline 1. Institutions & $5.16(22)$ & $4.00(64)$ \\
\hline 2. Infrastructure & $6.06(8)$ & $4.38(51)$ \\
\hline 3. Macroeconomic environment & $6.03(15)$ & $5.56(24)$ \\
\hline 4. Healthy and primary education & $6.50(14)$ & $6.16(42)$ \\
\hline 5. Higher education and training & $5.63(16)$ & $5.01(39)$ \\
\hline 6. Goods market efficiency & $4.97(23)$ & $4.52(49)$ \\
\hline 7. Labour market efficiency & $4.80(22)$ & $4.57(34)$ \\
\hline 8. Financial market development & $4.88(20)$ & $4.19(52)$ \\
\hline 9. Technological readiness & $6.11(10)$ & $5.20(34)$ \\
\hline 10. Market size & $5.99(5)$ & $3.15(96)$ \\
\hline 11. Business sophistication & $5.61(3)$ & $3.71(58)$ \\
\hline 12. Innovation & $5.58(5)$ & $3.36(64)$ \\
\hline
\end{tabular}

The small market size of Latvia takes into account the most negative. However, this circumstance is countered by an increase in export activities (Centrālās statistikas pārvaldes datubāzes, 2016c), which will be described more detailedly later. Furthermore, although the technology readiness in Latvia is present (5.20), innovations, which are especially in IT industry omnipresent, represent a weak point there (3.36). As mentioned above, Latvian institutions imply a potential of rising entrepreneurial aspirations through programs, i.e. in the way of the mentioned programs from Germany. However, from the German point of view, there is also an improvement potential in this sub-index. Not surprisingly, Germany's rankings, which are especially high in the sub-indexes 10, 11 and 12, are located above Latvia's rankings, as Germany portrays a more developed country (i.e. see GDP per capita comparison above), whereby macroeconomic environment has been evaluated as strength in Latvia in contrast to Germany, even if the Latvian score is lower than the German score. This good score for Latvia coincides with the above cited valuation from Geipele et al. (2016a).
With the help from GCI, strengths and weaknesses regarding competitiveness of business environments between the investigated countries were clarified, as business environments are playing a vital role for start-up companies.

\section{IT venture opportunities in Germany and Latvia}

\section{Business Innovation Ecosystem of the European Union: Overview of the current situation}

Through the great importance of promoting high-potential business ventures with regard to achieving a positive effect on economic growth and innovation, wellconsidered policies have been seen as forceful measures to gain advantages in entrepreneurial activities (Lerner, 2010). For this, start-up activities in the European Union were affected highly significantly by EU regional policies from 2000 to 2006, whereby positive effects on entrepreneurial activity opportunities occurred (Sternberg, 2012). Apart from that, for an enhancement of Europe's ability to innovate, the European Institute of Innovation and Technology (EIT) uses Knowledge and 
Innovation Communities (KICs), which get together fields of education, technology, research, business and entrepreneurship for generating inspirations for innovations (Riva, 2013).

Until now, the European Union has especially intensified their support to the emergence and development of IT industry, as they adjusted their fiscal and legal environments to the needs of small IT industry firms, leading to beneficial effects for IT ventures (Revest \& Sapio, 2012).

In recent years, there has been a significant increase in the use of entrepreneurship education in schools and universities in Europe (Johansen \& Schanke, 2013). This trend portrays another beneficial point for entrepreneurial activities in Europe, as education is supposed to promote general and specific entrepreneurial abilities and improves academic performance (Johansen, 2014).

A negative aspect underlies in the predominant lack of SMEs performing export activities, which is unfavourable (Muller et al., 2016). Especially the above mentioned digitalization and globalization arouse hope that this development will reverse in the future, leading to even better opportunities for SMEs.

As it is already known that business model environment, i.e. social environment, competitive forces, technological change, customer demand or legal environment is playing an important role for ventures (Osterwalder, 2010), a brief analysis of the business innovation ecosystems will be made for Germany and Latvia in order to serve as a basement for the evaluation of both countries. This analysis, in comparison to GCI, which only showed the business environment in general, focuses on innovation more detailedly.

\section{Business Innovation Ecosystems in Ger- many and Latvia: Overview of the cur- rent situation}

Evaluation of Innovation Ecosystems will occur in a quantitative way, using both data from publications about positive and negative aspects for both countries, and sum- marizing evaluations from Global Entrepreneurship Monitor (GEM) and Global Innovation Index (GII).

For Latvia, Aleksejeva and Aleksejeva (2015) have shown that regarding infrastructure, which was evaluated as an important factor of entrepreneurial success, experts evaluated communication infrastructure, namely Internet access, as well as mobile phone communications very positive, whereas quality of electricity supply and road quality were evaluated adversely. In another study about Latvia's business innovation success factors, good client service, honesty reputation, charisma and friendliness with clients were the most important success factors (Sloka, Kantāne, Avotiņš \& Jermolajeva, 2014). Furthermore, Kozlinska (2011) criticized quality and applicability of education, i.e. insufficient cooperation of universities and businesses or risk-averse and uncompetitive profiles, leading to less entrepreneurial activity. This circumstance goes hand in hand with the findings of Volkmann \& Tokarski (2009): Latvian students, in the opposite to Germany, were less inclined to see themselves as potential entrepreneurs (58.5\% in Latvia against $71.9 \%$ in Germany) and evaluated entrepreneurship less important for the future than German students (44.6\% in Latvia against $53.3 \%$ in Germany). This can be seen as a big disadvantage of Latvia, as Hilkevičs \& Štefenberga (2013) argued that innovative business is linked to a good cooperation of government, institutions and universities.

Germany, for itself, spends high investments in entrepreneurial research, namely 470 million $€$ (Federal Ministry of Education and Research, 2016). Furthermore, the number of entrepreneurship chairs at universities in Germany increased rapidly even from 1998 (Klandt \& Volkmann, 2006).

Regarding German IT industry, since late the 1990's a strong boom occurred, making start-up activities in this industry since 2006 with an amount of then-reached $15 \%$ of overall start-up activity to an important industry (Audretsch \& Keilbach, 2007). Nowadays, like it was said above, about $21 \%$ of business ventures are located in IT 
industry (KfW Research, 2016). For this, Germany can be seen as a technology-affine country.

Regarding Industry 4.0, which especially combines IT services with manufacturing industry, Germany's government has taken the lead to expand Industry 4.0, resulting in an inclusion of trade associations, ministries, unions and academics (The Econo- mist, 2015). For this, a bigger market for IT services is generated.

As mentioned above, GEM, which portrays an expert rating ranging from 1 (=highly insufficient) to 9 (= highly sufficient), will be used for the comparison of Germany's and Latvia's Entrepreneurial Ecosystems. The results are summarized in the following figure:

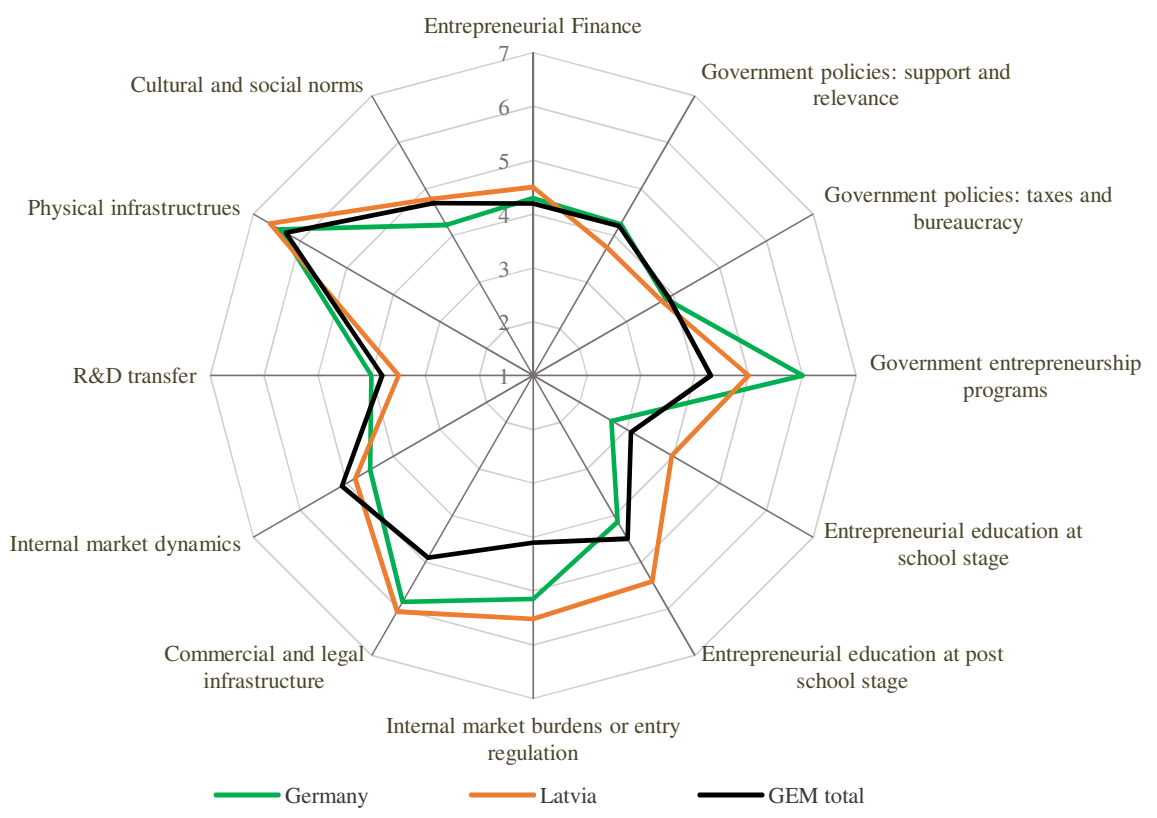

Figure 1: Expert Ratings from GEM Global Entrepreneurship Monitor (2016)

The graph shows that in comparison Latvia shows more positive results within the GEM results than Germany. According to the average of the countries under study, Germany's result shows - besides its highly efficient categories like commercial and legal infrastructure, internal market burdens or entry regulation as well as government entrepreneurship programs improvement potentials in entrepreneurial education at school stage and post school (and this, although a great upturn was already apparent in this area, like mentioned above). Especially in the latter two categories, Latvia performs very well, which should enable (potential) entrepreneus with important know-how. Nevertheless, R\&D transfer is weak in Latvia (which is an indicator for the bad results in GCI-Innovation-sub-index), and support and relevance of government policies should be higher. However, the above mentioned entrepreneurial education in Latvia as well as the country's highly sufficient market burdens enable potential founders to start their own business.

After evaluating both the business environments (GCI) in general and using a more detailed approach with GEM for an evaluation of the entrepreneurial ecosystem, another index will be used in the following. With the help of the above mentioned GII, a closer look to the main points of business innovation ecosystems of Germany and Latvia will be given. This approach implies an important point for IT start-up companies; as it has already been mentioned above, innovations play a vital 
role for business success within IT industry.

GII is ranging from 0 to 100 and ranks the innovation performance of 128 countries and economies, representing $92.8 \%$ of the world's population and $97.9 \%$ of global GDP, based on 82 indicators (GII, 2016). The main points of GII are summarized in the following table:

Table 2: Analysis of the GII (2016) for Germany and Latvia

\begin{tabular}{|l|l|l|}
\hline Sub-indexes & Germany & Latvia \\
\hline Institutions & $84.1(18)$ & $77.7(29)$ \\
\hline Human Capital and Research & $58.9(10)$ & $31.4(67)$ \\
\hline Infrastructure & $58.5(22)$ & $54.3(30)$ \\
\hline Market sophistication & $59.7(16)$ & $48.6(43)$ \\
\hline Business sophistication & $48.3(15)$ & $36.6(40)$ \\
\hline Knowledge and technology outputs & $51.6(8)$ & $31.6(41)$ \\
\hline Creative outputs & $56.3(7)$ & $46.2(25)$ \\
\hline
\end{tabular}

As it was explained in GCI, the numbers in brackets represent the ranking of the respective country. Regarding knowledge and technology outputs, which imply important aspects for IT industry and innovation potential, as they imply rankings about 'knowledge creation', 'knowledge impact' and 'knowledge diffusion', Germany performs very well, whereas Latvia seems to have some potential. Latvia ranks the best in creative outputs, which can be seen as important for the creation of innovations, as it combines 'intangible assets', 'creative goods and services' and 'online creativity'. This indicates a lack of support, which is needed in Latvia right now, i.e. through government support (which was evaluated as weak in the above detected GEM), to increase technology outputs. Especially through Latvia's weak results in Human Capital and Research (which combines secondary and tertiary education as well as R\&D) and market sophistication (which combines the main points 'credit', 'investment' and 'trade, competition \& market scale'), a more foreign-orientated business for start-ups in IT industry can be evaluated as advantageous for success. As the above-mentioned sub-index 'knowledge and technology' implies - regarding its three pillars - a big importance for IT industry, a more detailed view of GII will be given in the following table:

Table 3: Analysis of 'Knowledge and technology outputs' from GII (2016) for Germany and Latvia

\begin{tabular}{|l|c|c|}
\hline Knowledge and technology outputs & Germany & Latvia \\
\hline Overall & $51.6(8)$ & $31.6(41)$ \\
\hline 1. Knowledge creation & $66.4(6)$ & $12.3(58)$ \\
\hline 1.1 Patent applications by origin & $100.0(1)$ & $12.9(43)$ \\
\hline 1.2 PCT international applications by origin & $65.7(10)$ & $7.8(33)$ \\
\hline 1.3 Utility model applications by origin & $53.4(9)$ & - \\
\hline 1.4 Scientific and technical publications & $39.0(31)$ & $20.4(51)$ \\
\hline 1.5 Citable documents H index & $87.1(3)$ & $\mathbf{8 . 2 ( 7 6 )}$ \\
\hline 2. Knowledge impact & $45.7(26)$ & $55.0(10)$ \\
\hline 2.1 Growth rate of GDP per person engaged & $55.6(71)$ & $74.5(14)$ \\
\hline
\end{tabular}




\begin{tabular}{|l|c|c|}
\hline 2.2 New business density & $7.5(60)$ & $61.5(10)$ \\
\hline 2.3 Total computer software spending & $46.5(19)$ & - \\
\hline 2.4 IS0 9001 quality certificates & $30.6(27)$ & $42.9(18)$ \\
\hline 2.5 High-tech and medium high-tech output & $78.7(7)$ & $21.6(64)$ \\
\hline 3. Knowledge diffusion & $42.7(19)$ & $27.6(46)$ \\
\hline 3.1 Intellectual property receipts & $38.3(14)$ & $1.3(73)$ \\
\hline 3.2 High-tech exports & $48.5(15)$ & $26.1(25)$ \\
\hline 3.3 ICT services exports & $19.1(54)$ & $21.8(48)$ \\
\hline 3.4 Foreign direct investment, net outflows & $53.9(20)$ & $44.3(37)$ \\
\hline
\end{tabular}

As it is observable, the three pillars are subdivided in even more detailed subpillars. Sub-pillars, that play a vital role within IT industry, are further highlighted in yellow. Apart from that, especially good results in these sub-pillars are highlighted in green, especially bad results in red. As Germany reached good results in the overall sub-index, logically, many high rankings in the (sub-)pillars are noticeable as well. Those are the points $1.1,1.5$ and 2.5. Nevertheless, Germany has a weakness in 'ICT services exports'. In contrast, Latvia doesn't have strengths in any relevant subpillar regarding IT industry, but some big weaknesses in point 1.5 and 2.5. However, Latvia obtains some good results within 'knowledge impact'. Summarizing, the data from GII helped evaluating the Business Innovation Ecosystems, which implies a big importance for start-ups. Furthermore, the relevant rankings for IT-start-ups were filtered out, whereby advantageous and disadvantageous national circumstances have been made more visible.

In the following, an evaluation of IT venture possibilities in Germany and Latvia occurs, by using Porter's Five Forces.

\section{Evaluation of IT venture possibilities in Germany and Latvia}

In a panel of 50 executives, innovators, and thinkers from the Silicon Valley, both Germany and Latvia are seen as one of the twelve most promising countries over the world regarding an emergence in the technological sector, which is ranked at first place from China (The View from the Valley, 2014).
Results from previous research showed that a foreign-orientated start-up business may be beneficial for success (Hessels \& Van Stel, 2011; Acs \& Virgili, 2009). These results coincide with the above-mentioned proposal to pursue a more international orientation. Nevertheless, a clear disadvantage of Latvia was found, as Hessels and Van Stel (2011) argued that a positive effect of export-oriented start-ups on success is much higher in high-income countries like Germany. For this, the weak evaluation of Latvia's market size in GCI, which somehow urges Latvia to a foreign-orientated strategy, weighs even heavier.

In terms of IT industry and innovation in Latvia, a potential has been identified above. Results of Pelse and Zeverte-Rivza (2015) have shown the same, indicating low results in both IT usage and innovation in comparison to other member states of the EU, whereas competitiveness is improvable through new start-ups. This seems to be an indicator of Latvia's rising ratio of IT ventures in comparison to the total number of start-up companies, which was doubled from 2013 to 2015 (see Appendix 2) (Centrālās statistikas pārvaldes datubāzes, 2016a). Furthermore, exports of ICT products rose by $412 \%$ from 2008 to 2015, whereas total export, in comparison, only rose by $164 \%$ (Centrālās statistikas pārvaldes datubāzes, 2016c). Both indicate the attractiveness of IT market in Latvia. Even the above mentioned disadvantage of Latvia in terms of success reached through export-orientation seems to have no great influence, as export data in IT market show. Especially small businesses of one to nine employed people make up the bulk of the IT industry personnel (95\%) (Centrālās statistikas pārvaldes datubāzes, 
2016b). This also shows good opportunities for start-ups in this market.

In Germany, the above mentioned strengths and weaknesses of business environment and entrepreneurial ecosystem are confirmed by KfW, which sees strengths in the quality of infrastructure, image of Germany, free market access and

business support, whereas education system, credit availability and political engagement is evaluated weakly (KfW Research, 2016).

For IT industry, a special fund was established in 2005, giving support to 10.000 business plans and 440 start-ups so far, granting them financial and entrepreneurial support through public-private partnerships (Federal Ministry for Economic Affairs and Energy, 2016a). This measure seems necessary, as IT industry foundations stagnate or rather decline (ZEW, 2016). Furthermore, in comparison to Latvia, IT industry personnel in Germany mainly isn't located in small businesses, but in large companies (Destatis, 2016), which indicates stronger competition than in Latvia.

Regarding the previously obtained information or indicators about IT venture possibilities in Germany and Latvia, Five Forces Model from Porter (1980) was generated as a kind of final summary, combining evaluations ranging from "very low" (VL) and "low" (L), over "medium/low" (M/L), "medium" (M) and "medium/high" $(\mathrm{MH})$, to "high" $(\mathrm{H})$ and very high $(\mathrm{VH})$. From the point of view of IT start-ups (which are already in the market), those evaluations about the respective competitive forces are then assessed as "great disadvantage" (--), "disadvantage" (-), "low disadvantage" (=/-), "low advantage" $(=/+)$, "advantage" (+) and "great advantage" (++) according to start-up success. The results are summarized in the following figure:

\begin{tabular}{|l|c|c|}
\hline Competitive Forces & Germany & Latvia \\
\hline Rivalry & VH (--) & M (=) \\
\hline Entry barriers & $\mathrm{L}(-)$ & $\mathrm{M} / \mathrm{H}(=/+)$ \\
\hline Bargaining power of suppliers & $\mathrm{H}(-)$ & $\mathrm{VL}(++)$ \\
\hline Bargaining power of customers & $\mathrm{L}(+)$ & $\mathrm{M} / \mathrm{L}(=/+)$ \\
\hline Substitute threats & $\mathrm{VL}(++)$ & $\mathrm{M} / \mathrm{L}(=/+)$ \\
\hline
\end{tabular}

Figure 2: Analysis of the Competitive Forces in Germany and Latvia

IT personnel in Germany is mainly present in large companies, which should have a positive influence on expertise, quality and, thus, rivalry. Therefore, the latter was evaluated as "very high" in Germany, leading to a "great disadvantage" for IT startups. In Latvia, a large part of the IT industry is concentrated in very small companies, which should weaken rivalry. Nevertheless, the market size of Latvia is small and export ratios are exploding, which indicates a not to be ignored effect on rivalry. Both facts lead to a "medium"evaluation. In Germany, entry barriers are evaluated low, as a variety of supporting measures were explained. In Latvia, government support was evaluated weak, leading to a "medium/high"-evaluation of entry barriers. The very low bargaining power of suppliers is a great opportunity in Latvia, as there are not as many dominant companies in IT industry as in Germany, where large companies are predominant. An only marginal difference occurs in bargaining power of customers, as Latvia's IT use is still slightly lower than in Germany. Nevertheless, the high demanded and differentiated products from IT industry lower bargaining power of customers in both countries. At last, substitute threats are low, as switching costs 
in IT industry are high. Through the fact that IT is supplied by very small firms in Latvia, which may not have the quality standards of the German ones, the customer's propensity of substitutes can be seen higher in Latvia. Nevertheless, in summary, derived opportunities from Five Forces Model seem to be more available in Latvia.

\section{Conclusions and outlook}

The present paper shows many differences between Germany and Latvia regarding the above-formulated research questions:

- Regarding national circumstances, which affect the start-up behaviour, indicators like external business support services, quality of infrastructure, cultural differences, political and legal environment, access to finances and recruitment of professional and wellmotivated personnel have been detected.

- With respect to RQ 2, strengths and weaknesses from Germany and Latvia were detected within these indicators, as those were shown through several contributions from other scientific papers. Furthermore, the competitiveness of both business ecosystems was evaluated - as a kind of PESTEL approach by using GCI, in order to abstract beneficial and unbeneficial effects for startups.

- According to RQ 3, which is the key contribution of the paper, a kind of "ITstart-up"-ecosystem was generated for both Germany and Latvia. At first, GEM was used in order to focus on the Entrepreneurial Ecosystem, which shows up chances and risks for start-ups within the countries in general. Afterwards, GII was useful to focus upon the actual Business Innovation Subindexes with regard to filter out strengths and weaknesses of both countries regarding their competitiveness. Finally, an own Competitive Forces approach was made to focus upon the current situation from IT-start-ups' point of view.
Summarizing, both countries imply undoubtedly big chances for IT ventures coming from a wide range of different reasons mentioned above.

Giving an outlook for the future, the main challenge in Latvia in order to improve start-up opportunities in IT industry underlies in facilitating market entry (and exit) as well as in improving the general environment to improve the know-how of people with entrepreneurial aspirations (Manolova et al., 2008; Sauka \& Welter, 2007). Conceptual solutions to promote cooperation among science, research, business and government with regard to support founders portray an utter importance (Geipele, Geipele, Staube, Ciemleja \& Zeltins, 2016b). In fact, about $36 \%$ of IT start-ups only survive four years, with an even lower proportion after five years (Zhu \& Allee, 2008). Like it was shown in GCI, market size is a big disadvantage from Latvia, whereas export-orientation is further recommended.

In Germany, entrepreneurial education at school and post school level has to be improved (GEM, 2016; KfW Research, 2016). With an interdisciplinary approach, students from faculties other than economics (i.e. information technology) can be reached (Tchouvakhina, 2004), which logically - should lead to rising numbers of potential founders with entrepreneurial ambition in IT industry. Generally, entrepreneurial education, as it was described earlier, should be central in any nation's education policy to raise entrepreneurial activities (Johansen, 2014).

For the future, stagnating or even declining numbers of entrepreneurs are expected in Germany, facing them with the difficulty of maintaining their position as start-up culture (KfW Research, 2016). Founding ratio seems to be saturated there, whereas Latvia's detected opportunities definitely imply a huge chance of an economic growth progress triggered from start-up companies, especially through IT industry. 


\section{References}

1. Acs, Z. J. and Virgili, N. (2009), 'Entrepreneurship in developing countries,' Jena Economic Research Papers 2009-023.

2. Aleksejeva, V. \& Aleksejeva, L. (2015), 'Analysis of interconnection between small and medium sized enterprises and infrastructure in Latvia from 2009 to 2014.,' Regional Review/Regionalais Zinojums, (11), 29-43.

3. Ammetller, G., Rodríguez-Ardura, I. and Lladós-Masllorens, J. (2014), 'Entrepreneurial decisions: Insights into the use of support services for new business creation,' South African Journal of Business Management, 45 (4), 11.

4. Audretsch, D. B. and Keilbach, M. (2007), 'The localisation of entrepreneurship capital: Evidence from Germany. Papers In Regional Science,' 86 (3), 351-365.

5. Baumgartner, D., Pütz, M. and Seidl, I. (2013), 'What Kind of Entrepreneurship Drives Regional Development in European Non-core Regions? A Literature Review on Empirical Entrepreneurship Research,' European Planning Studies, 21 (8), 10951127.

6. Bednarzik, R. W. (2000), "The role of entrepreneurship in U.S. and European job growth,' Monthly Labor Review, 123 (7), 3.

7. Bisoux, T. (2002), 'On the Path to Prosperity,' Bized, 34.

8. Carraher, S. M., Buchanan, J. K. and Puia, G. (2010), 'Entrepreneurial need for achievement in China, Latvia, and the USA,' Baltic Journal of Management, 5 (3), 378396.

9. Centrālās statistikas pārvaldes datubāzes (2016a), 'SRG0201. Economically active enterprises by main kind of activity (NACE Rev. 2).' [Online], [Retrieved January 10, 2017],

http://data.csb.gov.lv/pxweb/en/uzreg/uz reg_ikgad_01_skaits/SRG0201.px/table/t ableViewLayout 2 /?rxid=a79839fe-11ba4ecd-8cc3-4035692c5fc8.
10. Centrālās statistikas pārvaldes datubāzes (2016b), 'ITG23. Number of ICT sector enterprises.' [Online], [Retrieved January 10, 2017], http://data.csb.gov.lv/pxweb/en/zin/ zin_datoriz_ikt_sektors/IT0230_29.px/ta ble/tableViewLayout2/?rxid=cdcb978c22b0-416a-aacc-aa650d3e2ce0.

11. Centrālās statistikas pārvaldes datubāzes (2016c), 'ITG27. Imports and exports of ICT products (mln euro).' [Online], [Retrieved January 10, 2017], http://data.csb.gov.lv/pxweb/en/zin/ zin_datoriz_ikt_sektors/IT0270_euro.px/t able/tableViewLayout $2 /$ ?rxid=cdcb978c22b0-416a-aacc-aa650d3e2ce0.

12. Chirjevskis, A. and Ludviga, I. (2009), 'Managing the Culture of Diversity: National and Cultural Identities as the basis of Sustained Competitive Advantages in Globalised Markets,' International Journal of Diversity in Organisations, Communities \& Nations, 9 (4).

13. De Clercq, D., Hessels, J. and Van Stel, A. (2008), 'Knowledge spillovers and new ventures' export orientation,' Small Business Economics, 31 (3), 283-303.

14. Destatis (2016), 'Statistik für kleine und mittlere Unternehmen.' [Online], [Retrieved January 16, 2017], https://www.genesis.destatis.de/ge ne-

sis/online;jsessionid=A40BA93251B918D1 096028642F3965E1.tomcat_GO_1_3?opera tion=previous\&levelindex=2\&levelid=1484 $573681490 \&$ step $=2$.

15. Dobele, L. (2011), 'Influencing factors of social entrepreneurship in Latvia,' Research for Rural Development, Proceedings of the International Scientific Conference, 2101-107.

16. The Economist (2015), 'Does Deutschland do digital? Germany's industry', The Economist, 417 (8965). [Online], [Retrieved December 21, 2016], http://elibraryusa.state.gov/primo?url=htt $\mathrm{p}: / /$

go.galegroup.com.vlib.interchange.at/ps/i. do? $p=S B R C \& s w=w \& u=w a s h 89460 \& v=2.1$ 
\&it=r\&id=GALE $\% 7 C A 450178185 \&$ asid $=83$ 03a8b2a0cd303821949ef41e086a35.

17. Edwards, S. (2002), 'Information Technology and Economic Growth in Developing Countries,'. Challenge, 45 (3), 1943.

18. Elam, A. and Terjesen, S. (2010), 'Gendered Institutions and Cross-National Patterns of Business Creation for Men and Women,' European Journal of Development Research, 22 (3), 331-348.

19. European Union (2015a), 'Germany.' [Online], [Retrieved December 30, 2016], http://europa.eu/european-union/abouteu/countries/membercountries/germany_en.

20. European Union (2015b), 'Latvia.' [Online], [Retrieved December 30, 2016], http://europa.eu/european-union/abouteu/countries/member-countries/latvia_en.

21. Federal Ministry for Economic Affairs and Energy (2016a), 'Machnig gibt Startschuss für Investorenaufruf zum HighTech Gründerfonds III - Zielvolumen 300 Millionen Euro.' [Online], [Retrieved January 18, 2017], http://www.bmwi.de/DE/Presse/pressem itteilungen, did=769706.html.

22. Federal Ministry for Economic Affairs and Energy (2016b), 'Unternehmensgründungen und Gründergeist in Deutschland.' [Online], [Retrieved January 16, 2017], http://www.bmwi.de/BMWi/ Redaktion/PDF/Publikationen/unternehmensgr uendungen-und-gruendergeist-indeutschland,property=pdf,bereich=bmwi2012,spra che $=$ de, $r w b=$ true.pdf.

23. Federal Ministry of Education and Research (2016), 'Industrie 4.0.' [Online], [Retrieved January 18, 2017], https://www.bmbf.de/de/zukunftsprojekt -industrie-4-0-848.html.

24. Gebhardt, C. (2012), 'The Entrepreneurial State: The German Entrepreneurial Regions' Programme as an Attenuator for the Financial Crisis,' European Planning Studies, 20 (9), 1469-1482.

25. Geipele, I., Geipele, S., Staube, T., Ciemleja, G. and Zeltins, N. (2016a), 'The Development of Nanotechnologies and Advanced Materials Industry in Science and Entrepreneurship: Socioeconomic and Technical Indicators. A Case Study of Latvia (Part One)', Latvian Journal of Physics \& Technical Sciences, 53 (4), 3-13.

26. Geipele, I., Geipele, S., Staube, T., Ciemleja, G. and Zeltins, N. (2016b), 'The Development of Nanotechnologies and Advanced Materials Industry in Science and Entrepreneurship: Socioeconomic and Technical Indicators. A Case Study of Latvia (Part Two),' Latvian Journal of Physics \& Technical Sciences, 53 (5), 31-42.

27. GEM Global Entrepreneurship Monitor (2016), 'The 2015 Global Entrepreneurship Monitor.' [Online], [Retrieved January 13, 2017], http://www.gemconsortium.org/report/4 9480.

28. Global Innovation Index (2016), 'Analysis.' [Online], [Retrieved January 13, 2017], https://www.globalinnovationindex.org/a nalysis-comparison.

29. Hessels, J. and Van Stel, A. (2011), 'Entrepreneurship, export orientation, and economic growth,' Small Business Economics, 37 (2), 255-268.

30. Hilkevičs, S. and Štefenberga, D. (2013), 'Problems of Latvia's regional economic development and innovative entrepreneurship,' Regional Review/Regionalais Zinojums, (9), 16-24.

31. Johansen, V. (2014), 'Entrepreneurship Education and Academic Performance,' Scandinavian Journal of Educational Research, 58 (3), 300-314.

32. Johansen, V. and Schanke, T. (2013), 'Entrepreneurship Education in Secondary Education and Training,' Scandinavian Journal of Educational Research, 57 (4), 357-368. 
33. KfW Research (2016), 'KfWGründungsmonitor.' [Online], [Retrieved January 18, 2017], https://www.kfw.de/PDF/DownloadCenter/Konzernthemen/Research/PDFDokumente-

Gr\%C3\%BCndungsmonitor/Gr\%C3\%BCnd ungsmonitor-2016.pdf.

34. Klandt, H. and Volkmann, C. (2006), 'Development and Prospects of Academic Entrepreneurship Education in Germany,' Higher Education In Europe, 31 (2), 195208.

35. Kozlinska, I. (2011), 'Contemporary approaches to entrepreneurship education,' Journal of Business Management, 4 (1), 205-220.

36. Landes, D. (2000), 'Culture Makes Almost All the Difference', In: L.E. Harrison and S.P. Huntington (eds.). Culture Matters: How Values Shape Human Progress, Basic Books: New York, NY, 2-13.

37. Lange, J., Leleux, B. and Surlemont, B. (2003), 'Angel Networks for the 21st Century: An Examination of Practices of Leading Networks in Europe and the U.S.,' The Journal of Private Equity, 6 (2), 18-28.

38. Lerner, J. (2010), 'The future of public efforts to boost entrepreneurship and venture capital,' Small Business Economics, 35 ( 3), 255-264.

39. Manolova, T. S., Eunni, R. V. and Gyoshev, B. S. (2008), 'Institutional environments for entrepreneurship: Evidence from emerging economies in Eastern Europe,' Entrepreneurship Theory and Practice, 32 (1), 203-218.

40. Muller, P.; Devnani, S.; Julius, J.; Gagliardi, D. and Marzocchi, C. (2016), 'Annual Report on European SMEs 2015/2016. SME recovery continues. Final report, November 2016.' [Online], [Retrieved December 27, 2016], http://ec.europa.eu/DocsRoom/document s/20264/attachments/1/translations/en/ renditions/native.

41. Osterwalder, A. and Pigneur, Y. (2010). Business model generation: a handbook for visionaries, game changers, and challengers. John Wiley \& Sons.

42. Pelse, M. and Zeverte-Rivza, S. (2015), 'Innovations and use of information and communication technologies in entrepreneurship in Latvia,' Engineering for Rural Development, Proceedings of the International Scientific Conference, 14, 681-687.

43. Peterka, S. O. and Saric, M. (2015), 'From idea to business venture (in pharmaceutical industry),' Contemporary Legal \& Economic Issues, (5), 281-305.

44. Porter, M.E. (1980), Competitive Strategy: Techniques for Analyzing Industries and Competitors. Free Press: New York.

45. Rajaei, Y., Yaghoubi, J. and Donyaei, H. (2011), 'Assessing effective factors in development of entrepreneurship in agricultural cooperatives of Zanjan province,' Procedia-Social and Behavioral Sciences, 15, 1521-1525.

46. Revest, V. and Sapio, A. (2012), 'Financing technology-based small firms in Europe: What do we know?,' Small Business Economics, 39 (1), 179-205.

47. Riva, G. (2013), 'CyberEurope,' Cyberpsychology, Behavior \& Social Networking, 16 (9), 715.

48. Romaní, G., Didonet, S., Contuliano, S. and Portilla, R. (2013), 'Propensity of University Students in the Region of Antofagasta, Chile to Create Enterprise,' Journal of Education For Business, 88 (5), 253.

49. Sauka, A. and Welter, F. (2007), 'Productive, unproductive and destructive entrepreneurship in an advanced transition setting: the example of Latvian small enterprises,' Empirical entrepreneurship in Europe, 87-111.

50. Schwab, K. (2016), 'Global Competitiveness Report 2016-2017.' [Online], [Retrieved January 12, 2017], http://www3.weforum.org/docs/G CR2016-2017/05FullReport/

TheGlobalCompetitivenessReport20162017_FINAL.pdf. 
51. Sloka, B., Kantāne, I., Avotin̄š, V. and Jermolajeva, E. (2014), 'The analysis of the factors promoting business success (Comparative studies in Latvia in Comparison with Canada, the USA, Mexico),' Regional Review / Regionalais Zinojums, (10), 5-14.

52. Statista (2017a), Anteil der Gründer an der Bevölkerung (Gründerquote) in Deutschland von 2000 bis 2015. [Online], [Retrieved January 17, 2017], https://de.statista.com/statistik/daten/stu die/183866/ umfrage/entwicklung-dergruendungsquoten-in-deutschland/.

53. Statista (2017b), Verteilung von Startups in Deutschland nach Marktneuheit des Angebots. [Online], [Retrieved January 17, 2017],

https://de.statista.com/statistik/daten/stu die/586336/umfrage/

verteilung-von-startups-in-deutschlandnach-marktneuheit-des-angebots/.

54. Sternberg, R. (2012), 'Do EU Regional Policies Favour Regional Entrepreneurship? Empirical Evidence from Spain and Germany,' European Planning Studies, 20 (4), 583-608.

55. Tchouvakhina, M. (2004), 'KfW and the promotion of entrepreneurship training in Germany,' Higher Education In Europe, 29 (2), 233-236.

56. The Atlantic (2014): 'The View From the Valley,' Atlantic, 314 (4), 78.

57. The World Bank (2015a), 'GDP per capita growth (annual \%).' [Online], [Retrieved December 30, 2016], http://data.worldbank.org/indicator/NY.G DP.PCAP.KD.ZG?name_desc=true.

58. The World Bank (2015b), 'GDP growth (annual \%).' [Online], [Retrieved
December 30, 2016], http://data.worldbank.org/indicator/NY.G DP.MKTP.KD.ZG?name_desc=true.

59. The World Bank (2015c), 'GDP growth (annual \%).' [Online], [Retrieved December 30, 2016], http://data.worldbank.org/indicator/NY.G DP.MKTP.KD.ZG?name_desc=true.

60. The World Bank (2015d), 'GDP per capita growth (annual \%).' [Online], [Retrieved December 30, 2016], http://data.worldbank.org/indicator/NY.G DP.PCAP.KD.ZG?name_desc=true.

61. Volkmann, C. K. and Tokarski, K. 0. (2009), 'Student attitudes to entrepreneurship,' Management \& Marketing, 4 (1), 17 38.

62. Welter, F. (2010), 'Sustaining entrepreneurship and economic growth: Lessons in policy and industry innovations from Germany and India,' In: Keilbach, M., Tamvada J. P. and Audretsch D. B. (eds.). Papers In Regional Science, 89 (1), 226227.

63. ZEW (2016), 'Gründungstätigkeit in Deutschland stagniert.' [Online], [Retrieved January 18, 2017], http://www.zew.de/fileadmin/FTP/junge unternehmen/jungeunternehmen_0816.pdf.

64. Zhu, Y. and Allee, M. (2008), 'New Technology Ventures: What Factors Lead to Success?,' Academy of Management Perspectives, 22 (2), 108-109. 


\section{Appendix}

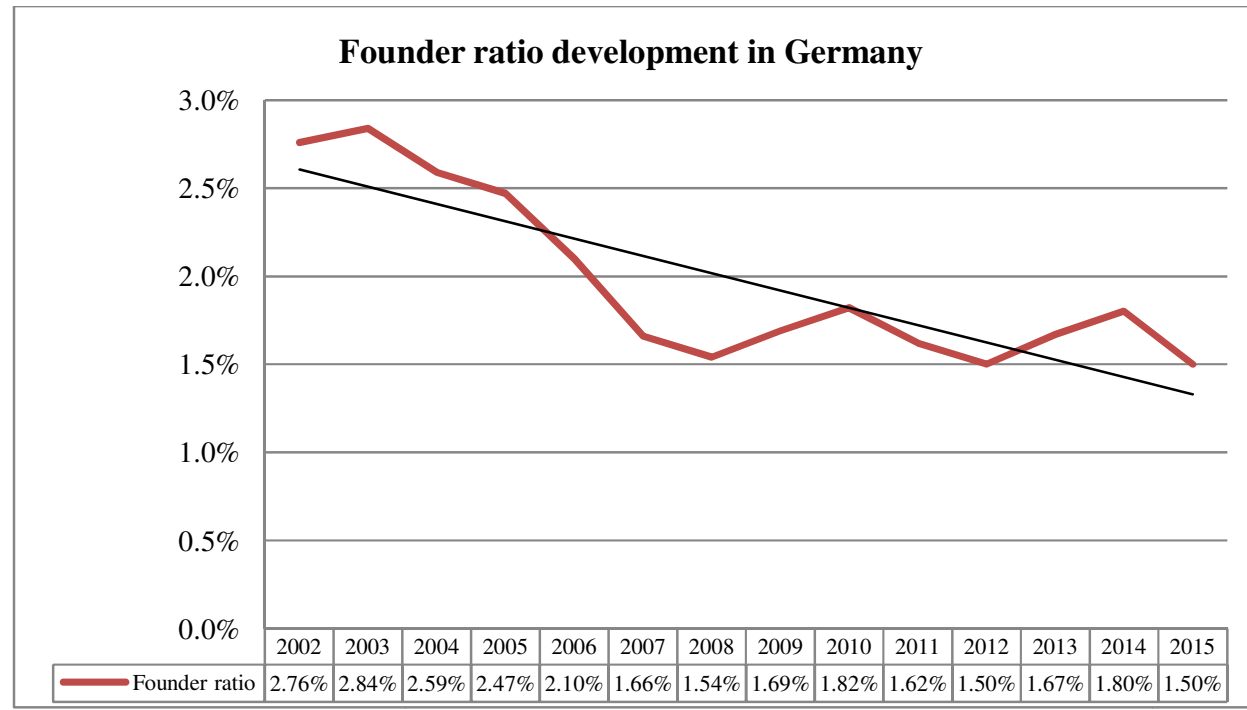

Appendix 1: Founder ratio development in Germany. Own elaboration using the data basis of KfW Research (2016) Data basis accessed at 16 ${ }^{\text {th }}$ January 2017.



Appendix 2: Ratio of self-employed people in IT industry in Latvia. Own elaboration using the data basis of Centrālās statistikas pārvaldes datubāzes (2016a). Data basis accessed at 13th January 2017. 